\title{
Historical Setting and Women's Welfare Legislation in Tamilnadu
}

\author{
V. Arulananthan \\ Ph.D., Research Scholar, Department of History, Thiru.Vi.Ka.Govt. Arts College, Thiruvarur.
}

In all societies, women have claimed equal status with men. It is of a vital importance in modern social science studies, and involves serious research. Progress in attitude, behavior, pattern and legal system is inevitable in all civilized societies. In a progressive society the rights and obligations were determined on the basis of status of an individual. This paper examines historically the status of special reference to Tamil Nadu women.

The level of culture of a particular society can very well be judged by the position of women in that society. Women especially the married one, enjoyed a position of respect and authority in the family as well as in society.

\section{Women in Tamil Society.}

Women, the better - half in the family life of a men, has always as significant role in the cultural life of Tamilnadu. There are considerable number of sources regarding the position of women in ancient Tamil society. How ever the modern terminology "Status of Women" and "Property Rights" of women in ancient Tamil Society is a questionable one. Through the ancient Tamil literature and women in Tamilnadu differed in many respects from that of the north Indian position. Purdhah system was vogue in north India. The women of ancient Tamil society possessed considerable freedom in the social life.

During the sangam period three types of marriages were adopted. The first was clandestive love and courtship which led to marriage, the second was getting bridge through a bull fight and third one was arranged marriage. The practice of the bride groom paying a certain amount of money to the parents of the girl had come in to the vogue. The payment of many to the bride-groom. There is no reference regarding the marriage symbol of tying of the "Thali" but, later it became an important part of the marriage ceremony.

The Hindu regarded marriage as can inescapable sacrament for girls and to keep a daughter unmarried was regarded as a sin and a neglect of a sacred obligation. The child marriages caused may evil practices in ancient society. The changes of early widowhood with all its misery in the case of girls were so many. The invasion of foreigners also a cause for the early marriages. Polygamy was not doubt, allowed, while monogamy was in vague. It was very common in all societies, from kings to ordinary man. Polygamy was not allowed in Indian society. But a few references traces the existence of that kind of marriage.

A Hindu wife is practically tied down to selfdom by the bonds of marriage. She can not under any circumstance snap the bond marriage was regarded as an indissoluble holy union and divorce was unknown except few examples of customay divorce in lower casts. Marriage of the sonlesses widow with her deceased husband's brother was allowed. Among the higher casts, widow were not allowed to remarry. The condition of a widow in early times was very pathetic. She was in auspicious unwanted and ill treated. Hindu religion does not command and people to tensure the head of their widows. The Kshatriyas do not observe. It this was practiced only by the upper class people. There is no services to explaining the genesis of the custom. It might have been copied from the Buddhists who adopted the shaving of hair as a symbol of renunciation.

Ancient Tamil society believed that the self immolation of a 'Sati' would lead her world of the Devas though the word 'Sati' is not there it was known as jumping in to the fire. Such women were known as Nallal. The method of sati were performed by the methods of Sahamarana and Anumarana. Thus women's of highest ranks in society showed their attachment to their husbands by performing 'Sati'. However it is not quite clear whether all the sections of society followed the same practices.

At the same time, the prostitution was an approved institution in early Tamil society. The courtesans were dancing girls in royal courts. The devadasis were temple dancing girls. The courtesans were different from devadasis and parathiyars. The prathayas were also well revised in music and dance. Few men married parathiyas, and accepted them as second wives. The lived out side of the city known as Prathiyar cheri, they were treated as out castes and were called kedaikali mahalir. They were different from women slaves of that period. The women slaves worked in the harms, royal from Tamil literature as well as from inscriptions. The role of spying during war time was remarkable one. 
The ancient Tamil sources tell about the devadasis, the Tamil literature and inscriptions speaks about the miseries and life style of devadasis. The subject of the devadasis can truly be called a slippery subject. At that time, the chief duties of the devadasis were to fan the deities of the devadasis were to fan the deities, clean the shrines, and to dance before the god during festivals. They also pleased rulers nobles, rich man, etc. The devadasis were married to god and thus they never become widow. In the marriage ceremonies the god was represented by an icon or even a sward. These hand maidens of god enjoyed a certain respectability in society. It was regarded as auspicious that the Thali an essential and holy insignia of marriage. Which was tied by an old lady of the classes of the devadasis.

This regettable condition of woman began to decline from the begining of the lath century by the social reforms and legislators.

\section{Challenges and response of the Pre - Independnt period}

The status of woman was an issue of great concern to $19^{\text {th }}$ century reforms in India. Their first efforts were directed against "sati", female infanticide, child marriages, devadasis, widow condition and other social evils of women. A first crucel activity of the Hindu was sati. In the begining of the nineteenth century, Particularly in 1818, They were hunderds of officialy noticed cases to sati in the province of Bengal. A number of cases took place all over India. Compare to north india. It was rare in Tamil Nadu in 1802, the two queens of Amessing the last reler of Thanjavour performed sati.

Raja Ram Mohan Ray was the leader of the Indian renaissance. He was on of the first champion of women's cause. He carried vigorous campain against sati on November 8, 1829 Lord William Bentinck expressed his views on suppression of 'sati'. Raja Ram Mohan Ray wrote a letter on the aims of the British administrators on December 4,1829, Regulation Act for abolition of sati was passed. Which declared the practice of sati was illegal and punishable as a criminal offence. In 1830 this Act was passed in Tamil Nadu.

Raja Ram Mohan Ray opposed polygamy any stressed on the need of removing the property disabilities of women. Other social reformers like D.N.Tagore, Ishwar Chandra Vidya Sagar, Swami Dyananda Saraswathi etc. Fought hard for the indroduction of female education, remarriage of widows, prevention of child marriage, removel of polygamy etc. The result of the consent effort of these reformens and thinkers, happend in 1856. When the widow remarriage Act was passed by the government even in the face of bitter opossition and raging contro versy from the orthodox people.

In 1802 the custom of throwing Hindu female children in to the sea was made criminal. At that time, above two thirds of female children were starved to death or poisoned by mothers. Attempts had been made to abolish the custom by Johathan Duncan, Benares in 1789. Duncan's activeties were continued early in the 19th centry by colonel walker of Baroda, Lord William Bentinck, Wilkinson and other worked with energy and enthusiasm and were successful. Female infanticide prevention Act 1870, was enacted by them.

The efforts of K.C.Sen against early marriages facilitated the enactment of Civil marriage Act of 1872. Other social thinkers of the $19^{\text {th }}$ century like M.G.Ranade, D.K.Karne, Rabindranath Tagore and other tried to inculculate in women. The siprit of values of the society by disseminating knowledge with the help of educational institutions. A number of Institutions were founded to impart education to gins like Mahila Vidyalada in 1907. D.K.Karve laid the foundation of the women's university in 1916.

Veera salingam pantalu, the great pioneer of social reform took up the cause of the untortunate child widows. Despite opposition he arranged the first widow - remarriage in Madras in June 1883. A widows home was founded in march 1902 with an initial strength of three inmales. The widow of these days did not possessed any property right. Because of her economic condition, she was dependent upon men. The Hindu law generally denied her right of inheritance. In a few cases she could inherit property, but such inheritance was only in the nature of limited right. The married women's property Act 1874, The Hindu Law of inheritance Amendment Act II of1937 etc. gave some limited preference to them.

The child marriage Restrains Act 1929 Popularly called the 'sarada Act' after its author, Harbilas sarda, fixed the minimum marriagable ages to boys and girls at 18 and 14 respectively. This Act considers the persons under those ages as children. It makes child marriages criminal and panishes with simple imprisonment up to one month and five up to Rs 1000 or both. Women are exempted from imprisonment.

The self Respect movement in Tamil Nadu under the ledership of periyar E.V.R. had strongly advocated the necessity in inter-caste marriage and widow marriages. The movement severely against the evils of child marriages and Devadasi system. It started propaganda for encouraging marriages of widows.

Although men were the first to take up the cause of Indian Women. Women too did not lag behind. Some of the outstanding women of the $19^{\text {th }}$ Century struggled against the prevelant condition and pursued with all sincerity the object of women's emancipation. Pandit Ramabai, Ramabai Ranade, Annandhabai Jashi, Annie Besent, Muthulakshmi Reddi, Subbulakshmi etc., were constantly engarged in their efforts to raise the social position of women. They gave guidance and direction to a 
movement. Which at that time was only in an embryonic stage. Their dauntless struggle against orthodox society become a source of inspiration for many women.

Mrs. Anni Besant Came to India in 1893, as a Theosophist the current of the movement swept her into the main stream as a pioneer among the cultural regenerators of the country. She condemned child marriages, encouraged widow remarriages and promoted the education for girls. She worked for the rightful recognition of women's position in society, recalling the Vedic ideas of equality.

The women's Indian Association which was formed in 1917 in Adayar, Madras has been the pioneer organizations for women in India that has done great service to enhance the progress of women's movement.

The troch bearers of this association were Mrs. Annie Besant and Mrs. Margaret Cautions who dedicated themselves to the service of country and emancipated Indian women. Annie Besent was the very sprit behind the women's Indian Association and become its first president Due to her efforts branches of the association spread out all over India. She took a leading port in demanding franchise for women of the same terms as men.

The Avvai Home and orphanage and a home for destitutes, was founded by the great visionary Dr.Muthulakshmi Reddi, She gave up her lucerative practice irresponse to the Womens Indian Association request and entered the Legislative council in 1907, as the First Women Legislator in British India. She was also unanimously elected the Deputy President of the Madras Council. She was essentially responsible for the agitation of the enforcement of child marriage Restraint Act, suppression of immoral traffic on women and girls in madras and abolition of the Devadasi System in the temples. She took a leading part in the women's Indian Association's Activities.

When the reformers tried to abolish devadasi system, the economic position of men and women of the community came in the way of rapid progress of the reform movement. The devadasis got income from the land of temples. So they could not voluntarily dissociate themselves from the temples. Hence Dr.Muthulakshmi Reddi sought, Government's intervention. A resolution introduced by She in 1928 recommended to enact an Act to abolish this system having accepted the resolution the madras government legislated in 1929. The Hindu Religious Endowments Act, It provided that women of the community need not perform service in temples and that the 'inams' intended for the service be entranchised and made over to the families of the devadasis. After considerably the various opinions expressed in this connection, the Devadasi Act was passed in 1947, with a view of stamp out the system.

Subbulakshmi Ammal, the child widow of Tamil Nadu Participated in the campaign for the abolition of child marriages and other evils. She founded the Sarada Ladies Union, the widows Home and the Sarada Vidyalaya. Thus the women of Tamil Nadu came out of the seclusion of their homes and started expressing themselves in education, politics, and public service and this was a process of self education and self development. Between 1917 and 1926, the History of the women's Association in Tamil Nadu was the history of women's movement in the state.

Moreover the freedom fighters, during the freedom struggle not only fought for independent but also for womens emancipation, Indian Poets, especially Tamil Poets wrote many poems and books regarding Indians freedom as well as for women's freedom. Vedahayaham pillai, Mahakavi Subramaniya Bharathi, Thiru.Vi.Kalyanasundaranar, Bharathidasan etc., were important Tamil Poets and social reformers who fought continuously against the social injustice done to women.

Vedanayaham pillai, provoked the Tamil society to educate women, especially the widows. Subramaniya Bharathi, the great poet of Tamil Nadu, Considered womens freedom as India's freedom. Bharathidasan the follower of Bharathi, rended his service to women's right. He pointed out that without women's freedom if would not be possible to achieve India's freedom. Thiru.Vi.Kalyanasundaranar, the famous social reforms as well as an efficient Tamil Scholar, was against the salavery of women. He praised the women as soul of society. He also encouraged education to women.

The spirit on which Mahatma Gandhi had involved women in the struggle for freedom has now come to be firmly enshrined in the constitution of Independent India. It promises to secure to all its citizens. Justice, social, economic, political, liberty of thought, expression, belief, faith and worship, equality of status and opportunity and to promote among them all frantenity assuring the dignity of the individual and the unity of the nation to attain those objectives, Indian constitution guarantees fundamental rights to all.

\section{The Constitutional Perspective}

The constitution of India is the fundamental law and source of all legislations whether social or otherwise fundamental Rights and Directive principles of state policy. Which are contained respectively in Part III and Part IV of the constitution constitute an important part of it. The fundamental rights assure individual freedom and the directive principles direct of the state to bring in a social order in which justice, social, political and economic prevails. 
Indian women are entitled to those benefits of these rights on part with men. Article 14 ensures "equality before the law" and Article 15 prohibits "any discrimination" Article 16 (1) guarantees "equality of opportunity. For all citizens in matters relation to employment or appointment to any office under the state. There are several other Articles that protect and cover the equality of women indirectly or by implication Article 3(a) (b) (c) (f) relates to ownership of material resources Article 40 gives right to organization to panchayats For self -government and article 41 for right to work employment and public assistance. Article 45 was enacted for all children up to the age of 14 and Article 47 For raising the standard of nutrition, and public heath. There are some other articles that have been described by commentators on the Indian constitution for women's welfare. These are Article 16(2) which "Forbids discrimination in respect to any employment of office under the state, on the grounds of religion, race, caste, sex, descent, place of birth, residency or any one of them.

Article 39 (1) promises the right to an adequate means at livelihood to men and women equally and Article 39(d) the equal pay for equal work for both men and women Article 39(e) gives protection for the health and strength of workers - men, women and children from abuse and entry into avocations unsuited to their age and strength and Article 42 gives just and human conditions of work and maternity relief. The important Article 15(3) provides for affirmative action and for protective discrimination by empowering the state to make any special provision for women and children.

All these constitutional provisions are backed by various legislations. Many of these legislations which were initially instituted in response to the reform movement of the nineteenth century have been subsequently revised to meet the constitutional commitments.

\section{References:}

[1] Mulladi Subbanma, women tradition and culture, sterling publishers pvt., Ltd., New Delhi 1982.

[2] Radhakrishnamoorthy, "Indian Women her position in society" Madras.

[3] Krishnakumari. N.S. Status of single women in India, Uppal Publishing House, New Delhi - 1987.

[4] Balasubramanian. C. The status of women in TamilNadu During the Sangam age, University of Madras, Madras 1976.

[5] Neelakanda Sastri. K.A. The culture and history of the Tamils, Tamil Publishing House, Madras 1964.

[6] Pillai K.K. The social History of the Tamils, University of Madras, 1975.

[7] Purnalingam. M.S. Tamil India, Saiva Sidhanta Publishing Society, Madras 1927.

[8] Otto Rahfeld, Women of India, R and R Clark Limited, Bombay 1928.

[9] Wilkins .W.J. Modern Hinduism, Cosmo Publications, New Delhi 1985.

[10] Sathiyanath Iyer, R. Cultural and Political History of India, Viswanathan Publishers, Madras.

[11] Tiwari .Y.K. Status of Hindu Women and Efficacy of Protective Legislations, Ashish Publishing House, New Delhi 1991.

[12] Raginidevi, Dance Diatects of India, Vikas Publications, Delhi 1975.

[13] Mahajen .V.D., India Since 1526, S.Chand \& Co., Delhi 1986.

[14] Majundar R.C. Struggle for Freedom, Bharatiya Vidya Bhavan, New Delhi 1988.

[15] Veeramani. K. Periyar on women's Rights, Emerald publishers, Madras 1992.

[16] Pillai Vedanayagam, Penkalvi, Saiva Sidhanta Kazham, Madras 1978.

[17] Eneyclopedia of Humanities and social sciences Vol.49, Jaipur, Anmul Publication 1992.

[18] Prakaya Rao V.V. Marriage the family and women in India, Heritage Publishers, New Delhi 1982. 